\title{
Pengaturan Motor Induksi Menggunakan Observer Self Constructing Fuzzy Neural Network dengan Metode Algoritma Pelatihan Levenberg Marquardt
}

\author{
Suhariningsih ${ }^{1,2)}$, Soebagio ${ }^{2)}$, Mauridhi Heri Purnomo ${ }^{2)}$ \\ ${ }^{1)}$ Politeknik Elektronika Negeri Surabaya- ITS \\ ${ }^{2)}$ Jurusan Teknik Elektro FTI, Institut Teknologi Sepuluh Nopember Surabaya \\ Kampus ITS Keputih Sukolilo Surabaya 60111 \\ E-mail : nuning@eepis-its.edu
}

\begin{abstract}
ABSTRAK
Dalam penelitian ini dikembangkan pengaturan kecepatan motor induksi 3 phase tanpa sensor yang dioperasikan dengan metoda Field Oriented Vector (FOC). Kecepatan motor diestimasi oleh suatu observer dengan suatu metoda Self Constructing Fuzzy Neural Network (SCFNN) dimana pelatihannya menggunakan metode algoritma pelatihan Levenberg Marquardt (LM), yang menggantikan metode Backpropagasi karena metode ini kurang cepat mencapai konvergen. Metode SCFNN mempunyai kemampuan untuk menggabungkan Fuzzy dan Neural Networks. Hasil simulasi menunjukkan sistem dapat mengestimasi fluksi dan kecepatan dengan kekonvergenan yang lebih cepat dari metode backpropagasi. Hasil estimasi dapat digunakan untuk mengidentifikasi kecepatan rotor motor induksi
\end{abstract}

Kata kunci: pengaturan kecepatan, motor induksi tanpa sensor, FOC, SCFNN observer, Levenberg Marquardt

\begin{abstract}
This paper describes about development of 3 phase speed sensorless induction motor speed controller using Field Oriented Vector(FOC) method. Motor speed is estimated by an observer using Self Constructing fuzzy Neural Network (SCFNN) with Levenberg Marquardt(LM) learning algorithm method, that replaces backpropagation method because this method is slow to reach convergent. SCFNN method combines the fuzzy and neural network. The simulation results show that the system can estimate flux and speed of induction motor and it converges faster than backpropagation method. .The estimation result can be used to identify rotor speed of induction motor with good performance
\end{abstract}

Keywords: speed control, induction motor, sensorless, FOC, SCFNN observer, Levenberg Marquardt

\section{PENDAHULUAN}

Motor DC merupakan jenis motor yang paling ideal untuk kontrol elektrik karena kecepatannya dapat diatur dengan mudah dan tidak memerlukan konverter. Kelemahan motor DC adalah harganya relatif mahal, ukurannya relatif besar, adanya komutator dan sikat-sikat dalam motor, sehingga memerlukan perawatan yang rumit dan harus dilakukan rutin. Selama perawatan operasi sistem terhenti, tentu ini sangat tidak dikehendaki dalam industri, karena akan sangat mengganggu proses dan mengurangi hasil (produksi) industri, yang berdampak pada kerugian perusahaan .

Catatan: Diskusi untuk makalah ini diterima sebelum tanggal 1 Desember 2008. Diskusi yang layak muat akan diterbitkan pada Jurnal Teknik Elektro volume 9, nomor 1, Maret 2009.
Kelebihan motor induksi selain kokoh, konstruksinya sederhana juga perawatannya mudah. Kelemahan motor induksi antara lain motor induksi merupakan motor yang tidak linier, metode untuk mengatur kecepatan rumit, disamping itu diperlukan suatu konverter yang dapat menimbulkan harmonisa. Namun setelah ditemukan suatu metode Field Oriented Control(FOC) yang mengubah sistem couple menjadi decouple, kesulitan dapat diatasi. Penggunaan metode ini menyebabkan motor induksi berfungsi seperti motor DC penguat terpisah. Dengan demikian motor induksi menggeser peranan motor DC dalam industri.

Dalam sistem pengaturan kecepatan motor induksi yang dioperasikan dengan metode FOC diperlukan suatu sensor kecepatan untuk 
mengamati nilai kecepatannya. Hasil pengamatan dari sensor kecepatan motor ini dibandingkan dengan kecepatan set point, yang kemudian diumpankan ke kontroller untuk bisa mengendalikan kecepatan sehingga sesuai dengan harga set point yang di-input-kan. Biasanya letak sensor terlalu jauh dari sistem kontrol maka proses pengamatan sensor pada motor induksi ini membuat hasil pengukuran kecepatannya menjadi kurang akurat. Untuk mengatasi masalah tersebut diperlukan suatu observer yang berfungsi untuk mengamati besar torka dan arus, sehingga kecepatan motor dapat diprediksi. Karena itu dikembangkan suatu observer menggunakan metode Selft Contructing Fuzzy Neural Network (SCFNN).

Sasaran dari penelitian ini adalah mengembangkan suatu observer metode Self Constructing Fuzzy Neural Network (SCFNN) dengan metode algorithm pelatihan Levenberg Marquardt yang menggantikan SCFNN dengan metode Backpropagasi yang dilakukan peneliti sebelumnya [1]. Metode ini digunakan untuk mengontrol kecepatan motor induksi 3 phase, sehingga motor mempunyai kinerja yang lebih bagus dengan pencapaian kekonvergenan yang lebih cepat.

Penelitian ini diharapkan memberi kontribusi terhadap upaya untuk terus mengembangkan metode pengaturan kecepatan pada motor induksi sehingga dapat meningkatkan kinerja yang lebih baik dari sistem yang menggunakan motor induksi. Dengan perbaikan kinerja sistem diharapkan meningkatkan efisiensi kerja pada dunia industri.

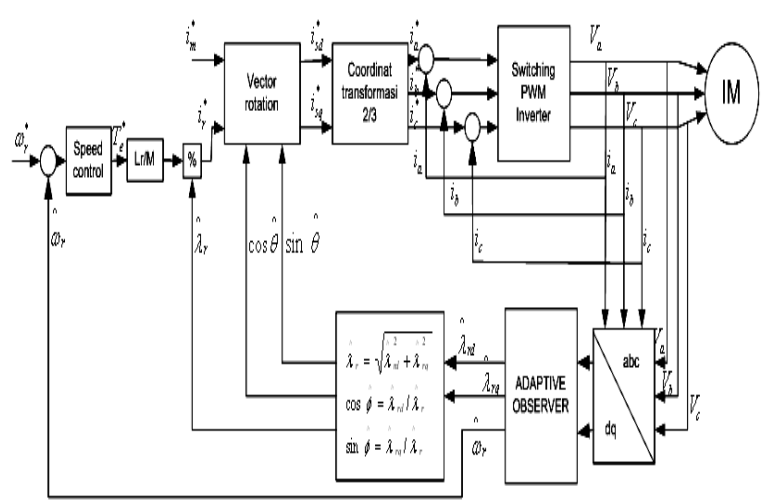

Gambar 1. Konfigurasi sistem speed-sensorless vector control untuk motor induksi dengan SCFNN[2]

\section{MODELING}

\section{Model Sistem}

Mengembangkan dari beberapa penelitian yang telah dilakukan oleh Seong-Hwan Kim, dkk.[3], Faa-Jeng Lin, dkk[4] dan Iradiratu DPK.[2], maka blok diagram sistem yang dikembangkan pada penelitian ini terlihat pada gambar 1 .

\section{Field Oriented Control}

Field Oriented Control (FOC) adalah suatu metode pengaturan medan pada motor AC, dimana dari sistem coupled diubah menjadi sistem decoupled. Dengan sistem ini arus penguatan dan arus beban motor dapat dikontrol secara terpisah, dengan demikian torka dan fluksi juga dapat diatur secara terpisah. Diagram blok yang menggambarkan prinsip dasar sistem decoupled field oriented control (FOC Decoupled) motor induksi ditunjukkan pada gambar 2 [5].

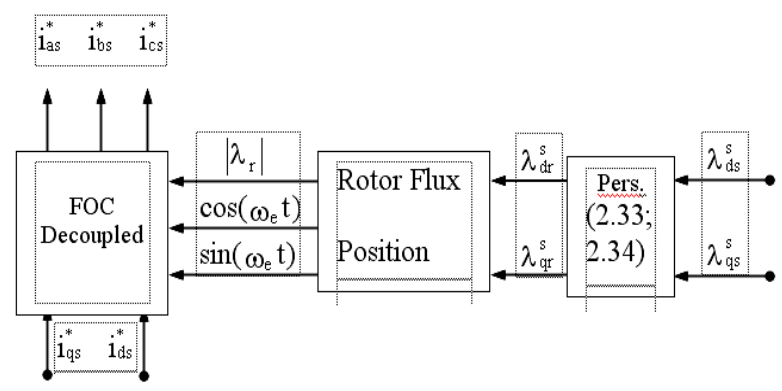

Gambar 2. Diagram blok FOC decoupled motor induksi

\section{Model Inverter}

Vektor rotasi terhadap arus magnetisasi dan arus torsi menghasilkan arus fase referensi yang digunakan untuk sinyal kontrol PWM inverter. Tegangan yang dihasilkan inverter akan digunakan oleh stator motor induksi. Model PWM inverter ditunjukkan pada gambar 3 .

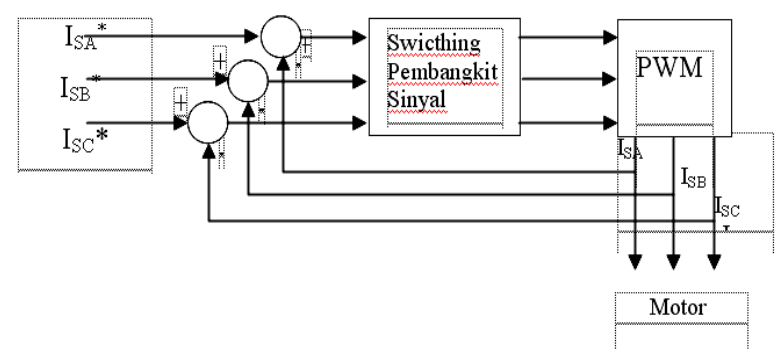

Gambar 3. PWM inverter 


\section{Model Motor Induksi}

Rangkaian ekivalen motor induksi dalam koordinat d-q dapat dilihat pada gambar 4 .

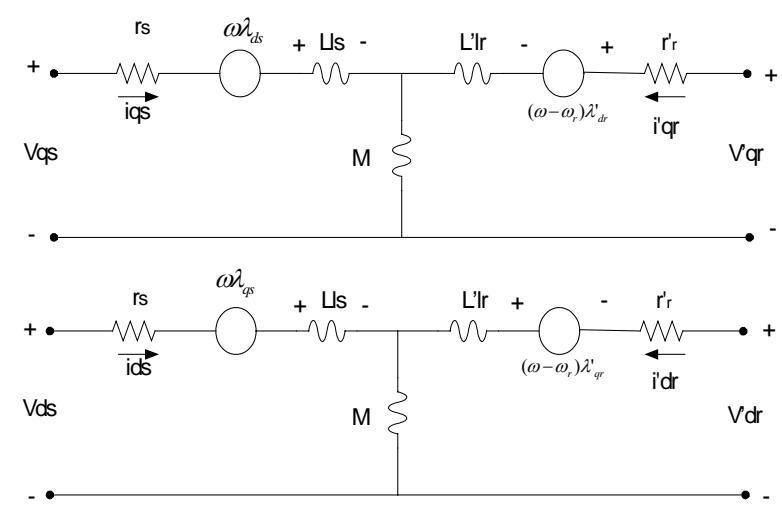

Gambar 4. Rangkaian ekivalen motor induksi dalam koordinat $d-q$

Dengan memasukkan tegangan rotor $\left(\mathrm{V}_{\mathrm{r}}=0\right)$ pada rangkaian ekivalen motor induksi dalam koordinat d-q, maka didapat besaran tegangan stator yang merupakan fungsi dari arus stator dan arus rotor dalam bentuk matrik sebagai berikut :

$\left[\begin{array}{c}v_{d s} \\ v_{q s} \\ 0 \\ 0\end{array}\right]=\left[\begin{array}{cccc}R_{s}+p L_{s} & -\omega_{s} L_{s} & p M & -\omega_{s} M \\ \omega_{s} L_{s} & R_{s}+p L_{s} & \omega_{s} M & p M \\ p M & -\left(\omega_{s}-\omega_{r}\right) M & R_{r}+p L_{r} & -\left(\omega_{s}-\omega_{r}\right) L_{r} \\ \left(\omega_{s}-\omega_{r}\right) M & p M & \left(\omega_{s}-\omega_{r}\right) L_{r} & R_{r}+p L_{r}\end{array}\right]\left[\begin{array}{l}i_{d s} \\ i_{q s} \\ i_{d r} \\ i_{q r}\end{array}\right]$

dengan: $p=\frac{d}{d t}$

Jika ditinjau pada koordinat stationer $\left(\omega_{\mathrm{s}}=0\right)$, maka persamaan 1 menjadi:

$\left[\begin{array}{c}v_{d s} \\ v_{q s} \\ 0 \\ 0\end{array}\right]=\left[\begin{array}{cccc}R_{s}+p L_{s} & 0 & p M & 0 \\ 0 & R_{s}+p L_{s} & 0 & p M \\ p M & \omega_{r} M & R_{r}+p L_{r} & \left.\omega_{r}\right) L_{r} \\ -\omega_{r} M & p M & -\omega_{r} L_{r} & R_{r}+p L_{r}\end{array}\right] \cdot\left[\begin{array}{l}i_{d s} \\ i_{q s} \\ i_{d r} \\ i_{q r}\end{array}\right]$

\section{SELF CONSTRUCTING FUZZY NEURAL NETWORK DENGAN METODE PELATIHAN LEVENBERG MARQUARDT}

Kontroler ini adalah sebuah kontroler fuzzy, sehingga masukannya adalah data numeric berupa nilai error. Struktur dasar dari sebuah fuzzy neural network adalah seperti pada gambar 5.[6]

Pada lapisan pertama hanya terjadi proses masukan berupa data crisp yaitu error $\left(\mathrm{X}_{1}\right)$ dan Delta error $\left(\mathrm{X}_{2}\right)$ untuk meneruskan sinyal ke lapisan berikutnya.
Pada lapisan kedua terjadi proses fuzzifikasi dan pembentukan membership fungsi. Fungsi yang dipergunakan adalah fungsi Gaussian.

$u_{A_{i}^{\prime}}=\exp \left(\frac{\left(x_{i}-m_{j i}\right)^{2}}{\sigma_{j i}^{2}}\right)$

dengan $m_{j i}$ dan $\sigma_{j i}$ adalah rata-rata (mean) dan standar deviasi.

Lapisan ketiga merupakan penentuan kondisi awal dari aturan fuzzy. Langkah ini adalah untuk memperoleh hasil perkalian antara semua komponen input dari error dan delta error dengan persamaan untuk rule node ke-j:

$$
u_{j}=u_{A_{1}^{j}}\left(x_{1}\right) u_{A_{2}^{j}}\left(x_{2}\right) \cdots u_{A_{n}^{j}}\left(x_{n}\right)=\prod_{i} u_{A_{i}^{j}}\left(x_{i}\right)
$$

Dengan $u_{j}$ adalah output node rule ke-j.

Lapisan keempat berfungsi untuk menjumlahkan seluruh sinyal masukan yang disimbolkan dengan $\Sigma$ kemudian dirumuskan dalam persamaan $y^{*}$ yang selanjutnya dilakukan proses defuzzikasi [6]

$y^{*}=\sum_{j=1}^{M} w_{j} u_{j}$

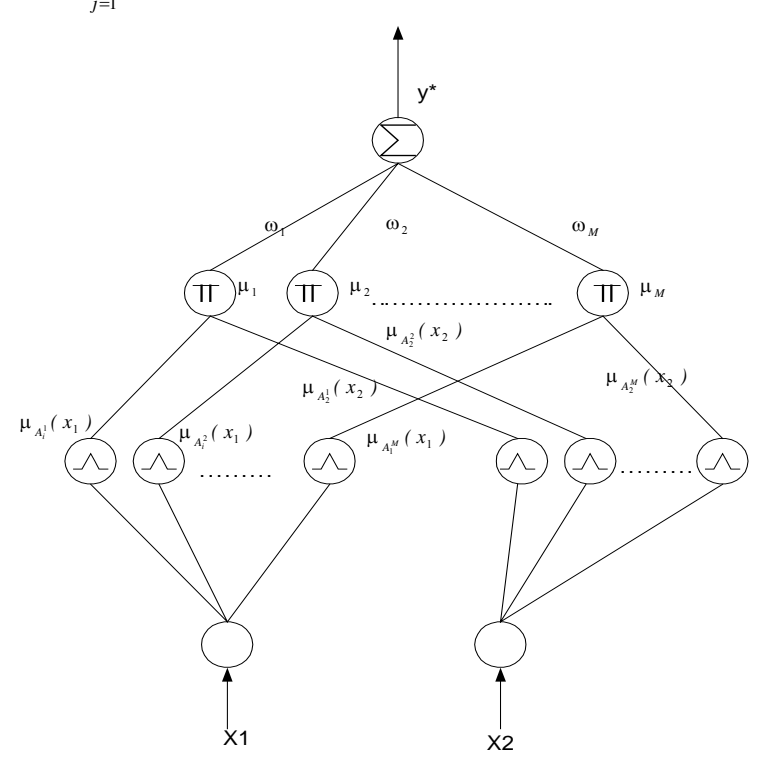

Gambar 5. Struktur dasar SCFNN

\section{Algoritma On-Line pada SCFNN dengan Metode Pelatihan Levenberg Marquardt}

Pada SCFNN terdapat dua jenis tipe algoritma pelatihan yaitu pelatihan struktur dan pelatihan parameter. Pelatihan struktur digunakan untuk 
mencari space input fuzzy logic partition dan fuzzy logic subject yang bertujuan meminimalkan jumlah rule dan meminimalkan fuzzy set dalam semesta pembicaraan dari setiap variabel input. Pelatihan parameter menggunakan algoritma supervised learning, sedangkan untuk menentukan bobot dan parameter dari membership function diatur dengan algoritma pelatihan backpropagasi.

\section{Fasa Pelatihan Struktur}

Langkah pertama pada pelatihan struktur adalah menentukan perlu tidaknya melakukan pelatihan struktur. Jika $e_{\min } \leq|e|$ atau $\Delta e_{\min } \leq|\Delta e|$, dimana $e_{\min }$ dan $\Delta e_{\min }$ adalah konstanta positif, maka Pelatihan struktur diperlukan. Selanjutnya menentukan node baru (membership function) pada lapisan kedua dan menghubungkan fuzzy logic rule pada lapisan ketiga. Jika adanya satu cluster diberikan pada input akan menyebabkan adanya sebuah rule fuzzy logic pada lapisan ketiga, maka persamaan kekuatan penyulutan (firing strength) dari sebuah rule untuk setiap data masukan $x_{i}$ dapat ditunjukkan sebagai sudut dimana data masukan memiliki hubungan terhadap cluster data. Firing strength diperoleh dari persamaan 4 yang digunakan sebagai pengukuran sudut :

$D_{j}=u_{j} \quad j=1, \ldots, Q(t)$

Dengan $Q(t)$ adalah jumlah rule yang ada pada waktu $t$. Kriteria pembentukan fuzzy rule baru untuk data masukan baru dinyatakan sbb. Dengan menentukan pengukuran sudut maksimum $\mathrm{D}_{\max }$

$D_{\max }=\max _{1 \leq j \leq Q(t)} D_{j}$

Jika $D_{\max } \leq \bar{D}$, maka dibentuk membership function dengan $\mathrm{D} \in(0,1)$. Kemudian mean dan standar deviasi dari membership function yang baru, dinyatakan lebih dulu dengan nilai tertentu secara heuristik atau cara lain. Jadi mean dan standar deviasi dari membership function baru sebagai berikut:

$$
\begin{aligned}
& m_{i}^{(\text {new })}=x_{i} \\
& \sigma_{i}^{(n e w)}=\sigma_{i}
\end{aligned}
$$

dengan $x_{i}$ adalah data masukan yang baru dan $\sigma_{i}$ adalah standard deviasi.
Untuk menghindari membership function yang baru sama dengan yang telah ada, kesamaan antara membership function yang lama dan baru harus diperiksa, yaitu dengan assumsi bahwa jika terdapat dua fuzzy set $\mathrm{A}$ dan $\mathrm{B}$ dengan membership function adalah $u_{A}(x)=\exp [-(x-$ $\left.\left.m_{1}\right)^{2} / \sigma_{1}^{2}\right]$ dan $u_{B}(x)=\exp \left[-\left(x-m_{2}\right)^{2} / \sigma_{2}^{2}\right]$, dan asumsikan $\mathrm{m}_{1} \geq \mathrm{m}_{2}$, maka $|\mathrm{A} \cap \mathrm{B}|$ dapat dihitung:

$$
\begin{aligned}
|A \cap B|= & \frac{1}{2} \frac{h^{2}(x)\left[m_{2}-m_{1}+\sqrt{\pi}\left(\sigma_{1}+\sigma_{2}\right)\right]}{\sqrt{\pi}\left(\sigma_{1}+\sigma_{2}\right)}+ \\
& \frac{1}{2} \frac{h^{2}(x)\left[m_{2}-m_{1}+\sqrt{\pi}\left(\sigma_{1}+\sigma_{2}\right)\right]}{\sqrt{\pi}\left(\sigma_{1}+\sigma_{2}\right)}+ \\
& \frac{1}{2} \frac{h^{2}(x)\left[m_{2}-m_{1}+\sqrt{\pi}\left(\sigma_{1}+\sigma_{2}\right)\right]}{\sqrt{\pi}\left(\sigma_{1}+\sigma_{2}\right)}
\end{aligned}
$$

$\operatorname{dimana} h(x)=\max \{0, x\}$

$$
E(A, B)=\frac{|A \cap B|}{|A \cup B|}=\frac{|A \cap B|}{\sigma_{1} \sqrt{\pi}+\sigma_{2} \sqrt{\pi}|A \cup B|^{*}}
$$

Pemeriksaan dilakukan pada semua variabel input $x_{i}$. Sedangkan nilai maksimumnya $E_{\max }$ didapat dengan:

$$
E_{\max }=\max _{1 \leq j \leq Q(t)} E\left\{u\left(m_{1}^{(\text {new })}, \sigma_{1}^{(\text {new })}\right), \quad u\left(m_{j 1}, \sigma_{j 1}\right)\right\}
$$

dimana $u\left(m_{j 1}, \sigma_{j 1}\right)$ adalah membership function Gaussian dengan mean $m_{j 1}$ dan standar deviasi $\sigma_{j 1} ; \mathrm{M}(\mathrm{t})$ adalah jumlah membership function ke-i dari variabel input. Jika $E_{\max } \leq \bar{E}$ dengan $\bar{E} \in$ $(0,1)$ adalah nilai yang sudah ditentukan, maka gunakan membership function baru dan jumlah $\mathrm{M}(\mathrm{t})$ adalah sebagai berikut:

$M(\mathrm{t}+1)=M(\mathrm{t})+1$

Jadi pembentukan membership function berhubungan dengan pembentukan rule fuzzy baru dan bobot $\omega^{\text {(new) }}$.

\section{Fasa Pelatihan Parameter}

Algoritma pelatihan parameter dari SCFNN adalah menentukan rule yang adaptif untuk mengatur parameter-parameter jaringan, berdasarkan pasangan input-output. Jika parameter jaringan terdiri dari vektor parameter, maka proses pelatihan memperhitungkan vektor determinasi dari fungsi energi. Metode ini umumnya berdasar rule pelatihan backpropagasi karena vektor gradien dihitung dalam arah berlawanan terhadap output setiap node. Untuk 
menjelaskan algoritma pelatihan parameter SCFNN menggunakan metode supervised gradient decent, asumsikan fungsi energi $E$ didefinisikan sebagai:

$$
E=\frac{1}{2}\left(\omega_{m}-\omega_{r}\right)^{2}=\frac{1}{2} e_{m}^{2}
$$

Kemudian algoritma pelatihan parameter berdasarkan backpropagasi dijelaskan sebagai berikut [6]:

Lapisan keempat; bentuk error dipropagasi dan dihitung sebagai berikut:

$$
\delta^{4}=-\frac{\partial E}{\partial y^{*}}=\left[-\frac{\partial E}{\partial e_{m}} \frac{\partial e_{m}}{\partial y^{*}}\right]=\left[-\frac{\partial E}{\partial e_{m}} \frac{\partial e_{m}}{\partial \omega_{r}} \frac{\partial \omega_{r}}{\partial y^{*}}\right]
$$

dan bobot di-update sebesar:

$$
\Delta \omega_{j}=-\eta_{\omega} \frac{\partial E}{\partial \omega_{j}}=\left[-\eta_{\omega} \frac{\partial E}{\partial y^{*}}\right]\left(\frac{\partial y^{*}}{\partial \omega_{j}}\right)=-\eta_{\omega} \delta^{4} u_{j}
$$

dengan faktor $\eta_{\omega}$ adalah parameter learning rate dari bobot. Bobot pada lapisan keempat diupdate dengan menggunakan persamaan:

$$
\omega_{j}(N+1)=\omega_{j}(N)+\Delta \omega_{j}
$$

dengan $\mathrm{N}$ adalah jumlah iterasi dari node ke-j

Lapisan ketiga; pada lapisan ini hanya error yang perlu dihitung dan dipropagasi:

$\delta_{j}^{3}=-\frac{\partial E}{\partial u_{j}}=\left[-\frac{\partial E}{\partial y^{*}}\right] *\left[\frac{\partial y^{*}}{\partial u_{j}}\right]=\delta^{4} \omega_{j}$

Lapisan kedua; error dihitung sebagai berikut:

$$
\delta_{j i}^{2}=-\frac{\partial E}{\partial u_{A_{i}^{j}}}=\left[-\frac{\partial E}{\partial y^{*}} \frac{\partial y^{*}}{\partial u_{j}}\right]\left[\frac{\partial u_{j}}{\partial u_{A_{i}^{j}}}\right]=\delta_{j}^{3}
$$

Hukum update dari $m_{j i}$ adalah:

$$
\begin{aligned}
\Delta m_{j i} & =-\eta_{m} \frac{\partial E}{\partial m_{j i}}=\left[-\eta_{m} \frac{\partial E}{\partial u_{A_{i}^{j}}} \frac{\partial u_{A_{i}^{j}}}{\partial m_{j i}}\right] \\
& =\eta_{m} \delta_{j i}^{2} \frac{2\left(x_{i}^{2}-m_{j i}\right)}{\left(\sigma_{j i}\right)^{2}}
\end{aligned}
$$

Hukum update dari $\sigma_{j i}$ adalah:

$$
\begin{aligned}
\Delta \sigma_{j i} & =-\eta_{\sigma} \frac{\partial E}{\partial \sigma_{j i}}=\left[-\eta_{\sigma} \frac{\partial E}{\partial u_{A_{i}^{\prime}}} \frac{\partial u_{A_{i}^{\prime}}}{\partial \sigma_{j i}}\right] \\
& =\eta_{\sigma} \delta_{j i}^{2} \frac{2\left(x_{i}^{2}-m_{j i}\right)}{\left(\sigma_{j i}\right)^{2}}
\end{aligned}
$$

dengan $\eta_{\mathrm{m}}$ dan $\eta_{\sigma}$ adalah parameter learning rate dari mean dan standar devisasi fungsi Gaussian. Mean dan standar deviasi dari membership function pada lapisan ini di-update dengan:

$m_{j i}(N+1)=m_{j i}(N)+\Delta m_{j i}$
$\left.\sigma_{j i}(N+1)=\sigma_{j i}(N)+\Delta \sigma_{j i}\right)$

Setelah didapatkan persamaan-persamaan ini maka disimulasikan rangkaian kontrol dengan Self Constructing Fuzzy Neural Networks dengan plant motor induksi.

Pada penelitian ini metode pelatihan Backpropagasi diganti dengan metode pelatihan Levenberg Merquardt (LM). Metode pelatihan LM ini merupakan kombinasi algoritma Newton dengan Steepest Decent. Bila metode Gradient Descent dinyatakan sebagai persamaan :

$W_{k j}(t+1)=W_{k j}(t)+\alpha \cdot \delta_{k} \cdot Z_{j}$

Persamaan di atas dapat disederhanakan menjadi

$W_{k+1}=W_{k}+\alpha \cdot g$

Dimana $g$ adalah vektor gradient. Bentuk persamaan Newton adalah:

$W_{k+1}=W_{k}-A_{k}^{-1} \cdot g$

$A_{k}$ adalah matrik Hessian (elemennya adalah turunan kedua error terhadap bobot) sebagai berikut:

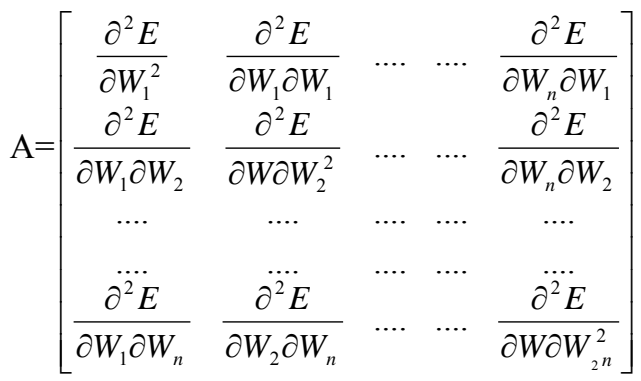

Matrik A dapat ditulus menjadi: 
$A=2 J^{T} J$

dimana $J$ adalah matrik Jacobian

Persamaan update bobot dengan metode pelatihan LM adalah :

$W_{k+1}=W_{k}-\left(J_{k}^{T} J_{k}+\mu I\right)^{-1} J_{k}^{T} e$

Bila nilai $\mu=0$, maka metode pelatihan LM akan sama dengan metode Gauss Newton, sedangkan bila $\mu$ maka metode pelatihan LM akan sama dengan Backpropagasi(steepest descent)[2].

Setelah didapatkan persamaan-persamaan ini maka disimulasikan rangkaian kontrol dengan Self Constructing Fuzzy Neural Networks metode pelatihan Levenberg Marquardt dengan plant motor induksi.

\section{BLOK DIAGRAM SELF CONTRUCTING FUZZY NEURAL NETWORK OBSERVER (SCFNNO)}

Blok diagram sistem kontrol kecepatan motor induksi tanpa sensor kecepatan dapat dilihat pada gambar 1. Bagian adaptive observer menggunakan self contructing fuzzy neural network terlihat pada gambar 6 dan gambar 7 .

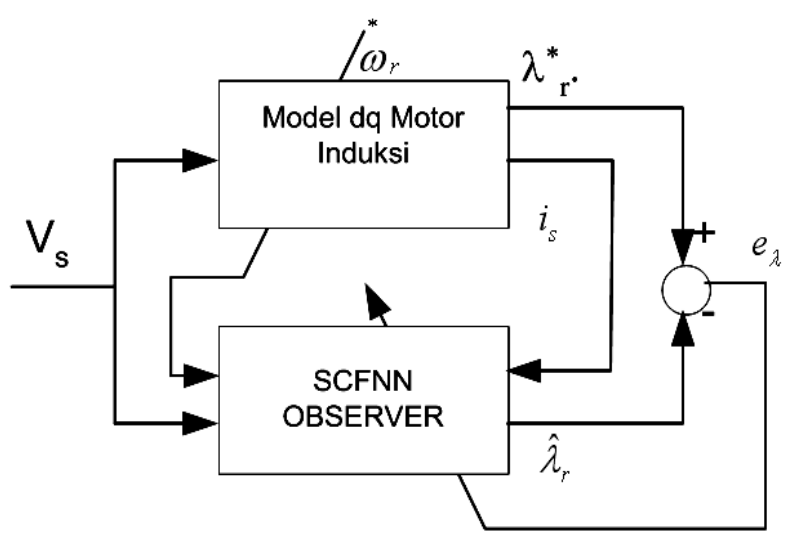

Gambar 6. Struktur estimasi fluksi

Gambar 6 adalah struktur estimasi untuk mendapatkan estimasi fluksi yang masingmasing terdiri dari fluksi direct $\lambda_{d r}$ dan fluksi quadrater $\lambda_{q r}$. Hasil dua parameter ini digunakan untuk input estimasi kecepatan seperti terlihat pada gambar 7 .

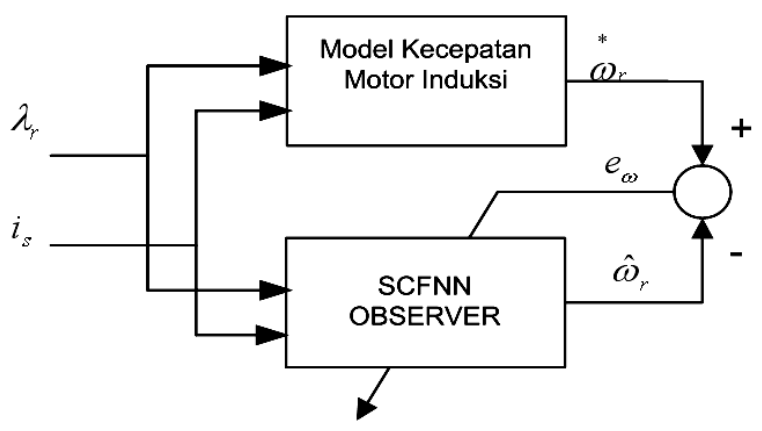

Gambar 7. Struktur estimasi kecepatan

Parameter motor induksi untuk data pelatihan SCFNN yang digunakan dalam mendapatkan target adalah:

a. Fluksi direct $\lambda_{d r}$ terdiri atas $I_{d s}, V_{d s}, V_{q s}$ dan $\omega_{r}$

b. Fluksi quadratur $\lambda_{q r}$ terdiri atas $I_{q s}, V_{q s}$, $V_{q s}$ dan $\omega_{r}$

c. Kecepatan $\omega_{\mathrm{r}}$ terdiri atas $\lambda_{d r}, \lambda_{q r} I_{d s}$, dan $I_{q s}$.

\section{Pembelajaran Off-Line}

Metode pembelajaran untuk estimasi fluksi identifikasi kecepatan motor induksi tiga fasa menggunakan self constructing fuzzy neural network, dimana jaringannya terdiri dari empat lapisan, yaitu 4 input, linguistic, precondition dan 1 output. Linguistic, precondition dan output digunakan untuk mendapatkan nilai $\lambda_{d r}, \lambda_{q r}$ dan $\omega_{r}$.

Proses pembelajaran menggunakan 4 neuron input yaitu $\mathrm{V}_{\mathrm{s}}, \mathrm{I}_{\mathrm{s}}, \omega_{r}^{*}$ dan $\lambda_{r}$. Pembelajaran dilakukan sebayak 5 epoch. Apabila hasil pembelajaran belum konvergen atau tidak sesuai target maka akan terjadi penambahan membership function baru. Penambahan akan berhenti bila hasil pembelajaran konvergen. Harga awal bobot ditentukan antara 0 dan 1 untuk mencari parameter optimal yang menghasilkan kinerja terbaik.

Dalam proses estimasi, ada tiga SCFNN untuk menyelesaikan estimasi fluksi direct $\lambda_{d r}$, fluksi quadratur $\lambda_{q r}$. Setelah selesai proses ini ada satu SCFNN menyelesaikan estimasi kecepatan $\omega_{r}$. 


\section{Pembelajaran Off-line Fluksi Direcf $\lambda_{d r}$}

Pembelajaran off-line self constructing fuzzy neural network observer untuk identifikasi fluksi direct $\lambda_{d r}$, ditunjukkan pada gambar 8 .

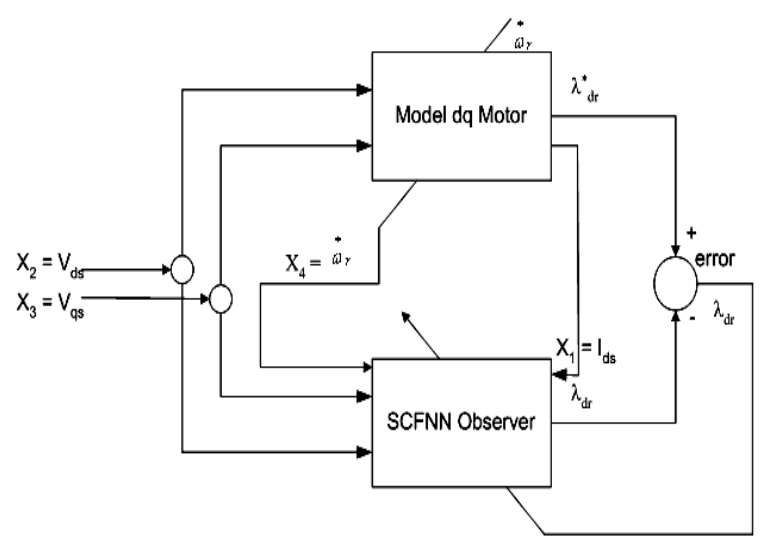

Gambar 8. Sruktur estimasi fluksi direct $\lambda_{d r}$ menggunakan SCFNNO

Gambar 8 menggambarkan tentang struktur dari estimator fluksi direct $\lambda_{d r}$ menggunakan SCFNN dan input terdiri atas $I_{d s}, V_{d s}, V_{q s}$ dan $\omega_{r}$, masuk ke blok SCFNNO.

Blok model motor menentukan nilai kecepatan (kecepatan referensi $\omega_{r}^{*}$ ) sehingga didapatkan fluksi direct referensi $\lambda_{\mathrm{dr}}^{*}$. Bagian SCFNNO menghasilkan fluksi direct pelatihan $\hat{\lambda}_{d r}$. Selisih nilai referensi dan pembejaran didapatkan error atau fluksi direct estimasi.

Output dari SCFNNO didefinisikan sebagai fluksi direct pelatihan $\hat{\lambda}_{d r}$, yang kemudian digunakan sebagai input yang dapat diubah-ubah. Jika fluksi direct yang diestimasi merupakan deviasi dari fluksi direct sesungguhnya dan error hubungan antara flux dari model fluksi direct pelatihan $\hat{\lambda}_{d r}$ dan fluksi direct referensi $\lambda_{d r}^{*}$, maka error merupakan backpropagasi dari SCFNN dan pembebanan dari SCFNN adalah adjusted on line untuk mengurangi error. Akhirnya, output dari SCFNN merupakan model fluksi direct yang sesungguhnya.

\section{Internal Struktur Dari SCFNNO}

Gambar 9 menggambarkan tentang struktur dari SCFNNO dan dilatih dengan algoritma backpropagasi untuk mendapatkan hasil SCFNN yang mengikuti kecepatan yang sesungguhnya.

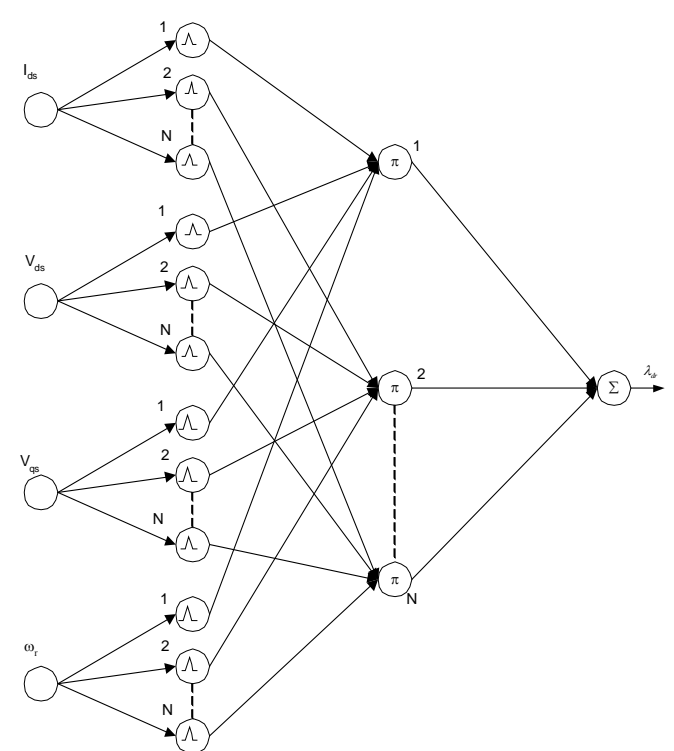

Gambar 9. Internal struktur SCFNNO

Jumlah blok SCFNNO ada 3 yaitu blok untuk SCFNNO $\lambda_{d r}, \lambda_{q r}$ dan $\omega_{r}$, blok SCFNNO untuk $\lambda_{d r}$ dan $\lambda_{\text {qr }}$ yang dihitung dulu, kemudian hasilnya dimasukkan ke blok SCFNNO $\omega_{r}$.

Pada saat pelatihan, jumlah rule yang tercipta untuk masing-masing input bisa berbeda dari rule yang tercipta untuk satu blok SCFNNO, karena karakteristik $I_{d s}, I_{q s}, V_{d s}, V_{q s}$ dan $\omega_{r}$ tidak sama.

\section{SIMULASI}

Data motor induksi tiga fasa yang digunakan untuk simulasi adalah:

Rs (resistansi stator) $=176 \mathrm{ohm}$, Tegangan 115 Volt

$\operatorname{Rr}$ (resistansi rotor) $=190 \mathrm{ohm}$, Jumlah pasang kutub $=2$

Ls (induktansi stator) $=3,79 \mathrm{H}$, Frekuensi $60 \mathrm{~Hz}$

$\mathrm{Lr}$ (induktansi rotor) $=3,31 \mathrm{H}$

$\mathrm{M}$ (induktansi gandeng) $=3,21 \mathrm{H}$

$\mathrm{J}($ momen inersia $)=0,0000105 \mathrm{Kg} \cdot \mathrm{m}^{2}$

$\mathrm{Kd}($ konstanta gesek $)=1,9 \cdot 10^{-5} \mathrm{Kg} \cdot \mathrm{m}^{2} / \mathrm{s}$

Gambar 10 dan gambar 11 merupakan hasil simulasi yang diperoleh untuk estimasi fluksi dan kecepatan rotor dengan menggunakan bahasa pemrograman $\mathrm{C}^{++}$. Performansi yang ditunjukkan menampilkan pengambilan data pada kecepatan 
referensi $1350 \mathrm{rpm}$. Gambar yang ditampilkan adalah hasil observer menggunakan SCFNNO pelatihan Levenberg Marquardt dan SCFNNO pelatihan Backpropagasi yang telah dilakukan peneliti sebelumnya [1].
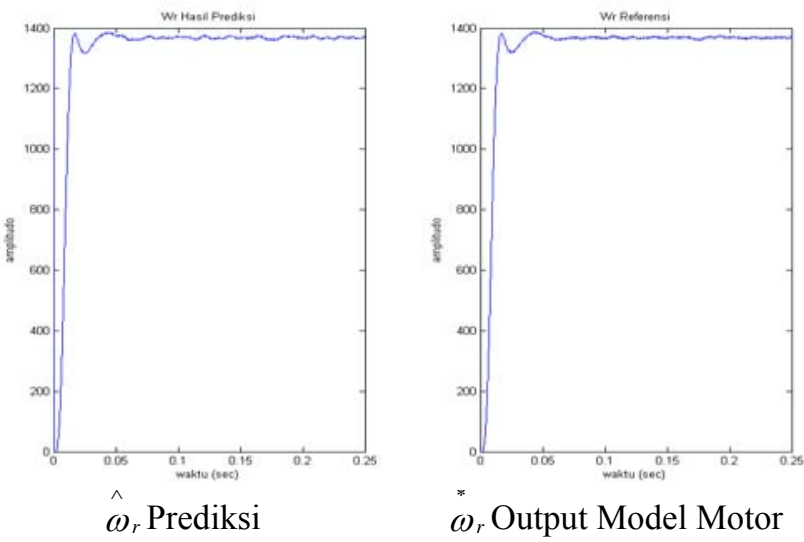

Gambar 10. Grafik kecepatan fungsi waktu dengan SCFNNO levenberg marquardt nilai MSE 0,017175\%

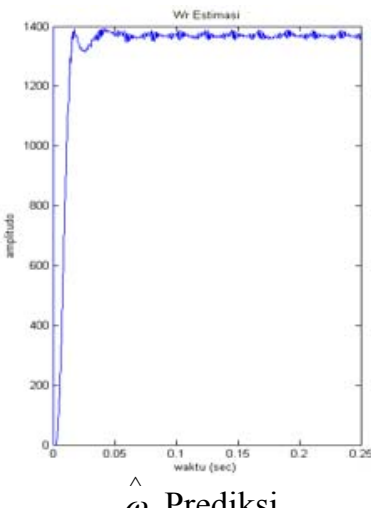

$\omega_{r}$ Prediksi

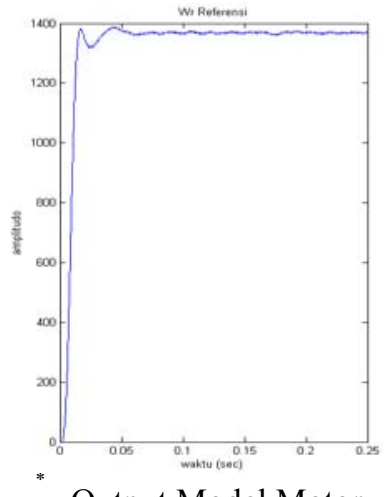

$\omega_{r}$ Output Model Motor
Gambar 11. Grafik kecepatan fungsi waktu dengan SCFNNO backpropagasi nilai MSE $0,030675 \%$

Tabel 1. Pengujian SCFNNO dengan pelatihan levenberg marquardt dan SCFNNO dengan pelatihan backpropagasi untuk beberapa data yang berbeda

\begin{tabular}{|c|c|c|c|c|c|c|}
\hline \multirow{3}{*}{ No } & \multirow{3}{*}{$\begin{array}{l}\text { Kecepatan } \\
\text { referensi } \\
\quad(\text { rpm) }\end{array}$} & \multirow{3}{*}{$\begin{array}{c}\text { Hasil } \\
\text { prediksi } \\
\text { pada }\end{array}$} & \multicolumn{4}{|c|}{ SCFNN Observer } \\
\hline & & & \multicolumn{2}{|c|}{$\begin{array}{l}\text { Levenberq } \\
\text { Marquardt }\end{array}$} & \multicolumn{2}{|c|}{ Backpropagasi } \\
\hline & & & $\begin{array}{c}\text { Jumlah } \\
\text { epoch }\end{array}$ & MSE (\%) & $\begin{array}{c}\text { Jumlah } \\
\text { epoch }\end{array}$ & MSE (\%) \\
\hline \multirow{3}{*}{1} & & $\lambda_{\mathrm{dr}}$ & 2 & 0,010360 & 50 & 0.020035 \\
\hline & 1350 & $\lambda_{\mathrm{qr}}$ & 2 & 0,019923 & 50 & 0,081165 \\
\hline & & $\omega_{\mathrm{r}}$ & 2 & 0,017175 & 50 & 0,030675 \\
\hline \multirow{3}{*}{2} & & $\lambda_{\mathrm{dr}}$ & 2 & 0,003539 & 50 & 0,056819 \\
\hline & 750 & $\lambda_{\mathrm{qr}}$ & 2 & 0,024703 & 50 & 0,080676 \\
\hline & & $\omega_{\mathrm{r}}$ & 2 & 0,021564 & 50 & 0,036961 \\
\hline \multirow{3}{*}{3} & & $\lambda_{\mathrm{dr}}$ & 2 & 0,027750 & 50 & 0,060614 \\
\hline & 500 & $\lambda_{\mathrm{qr}}$ & 2 & 0,018828 & 50 & 0,125130 \\
\hline & & $\omega_{\mathrm{r}}$ & 2 & 0,020052 & 50 & 0,049025 \\
\hline
\end{tabular}

\section{KESIMPULAN}

Dari pengamatan dan analisis hasil simulasi SCFNNO pelatihan Levenberg Marquardt pada penelitian ini dan kemudian dibandingkan dengan SCFNNO pelatihan Backpropagasi yang telah dilakukan peneliti sebelumnya, maka dapat disimpulkan:

1. Pada simulasi pelatihan pada simulasi SCFNNO Marquardt diperlukan jumlah epoch yang lebih sedikit dengan error yang lebih kecil dibanding dengan SCFNNO Backpropagasi. Hal ini berarti bahwa metode SCFNNO pelatihan Levenberg Marquardt lebih cepat konvergen dibanding dengan SCFNNO dengan pelatihan Backpropagasi.

2. Simulasi estimasi kecepatan $\left(\hat{\omega}_{r}\right)$ dengan SCFNNO pelatihan Levenberg Marquardt dengan pengambilan referensi kecepatan yang berbeda (yaitu $1350 \mathrm{rpm}, 750 \mathrm{rpm}$, $500 \mathrm{rpm}$ ), nilai Mean Square Error (MSE) berkisar antara $0,017175 \%$ sampai $0,021564 \%$.

Dari data tersebut dapat disimpulkan bahwa nilai MSE SCFNNO pelatihan Levenberg Marquardt mempunyai kisaran nilai yang lebih rendah dari SCFNNO pelatihan Backpropagasi. Hal ini menunjukkan bahwa Self Constructing Fuzzy Neural Network Observer yang dirancang mampu mengestimasi fluksi dan kecepatan rotor dengan baik karena nilai yang diijinkan Standart Error Estimasi (SEE) kurang dari $5 \%$

Dengan demikian metode SCFNNO pelatihan Levenberg Marquardt yang dirancang mempunyai performansi yang lebih baik dari pada SCFNNO pelatihan Backpropagasi sehingga dapat digunakan sebagai piranti alternatif untuk identifikasi kecepatan rotor motor induksi.

\section{DAFTAR PUSTAKA}

[1] Sutedjo, Soebagio dan Mauridhi Hery Purnomo, "Kendali Kecepatan Motor Induksi Tanpa Sensor Kecepatan Menggunakan Self Conructing Fuzzy Neural Network", Seminar Nasional XII FTI-ITS, 29 Maret 2005, hal. 414.

[2] Iradiratu, Mauridhi Hery Purnomo, Era Purwanto, "Perancangan Model Observer 
Untuk Identifikasi Kecepatan Motor Induksi”, Procedings SMED, Sep 2002.

[3] Seong-Hwan Kim,Tae-Sik Park,Ji-Yoon Too, and Gwi-Tae Park, "Speed-Sensorless Vector Control Of An Induction Motor Using Neural Network Speed Estimation", IEEE Trans. On Industry Application, vol. 48, No. 3, June 2001.

[4] F.J.Lin, W.J.Huang, and R.J.Wai, "A Supervisory Fuzzy Neural Network Control System For Tracking Periodic Inputs", IEEE Trans. Fuzzy Syst, vol.7, Feb.1999, pp.4152.

[5] Fukuda and T. Shibata, "Theory And Applications Of Neural Network for Industrial Control System", IEEE Trans. Ind. Electron, vol.39, Dec. 1992, pp.472489.

[6] Faa-Jeng Lin and Chih-Hong Lin, "A Permanent magnet Synchronous Motor ServoDrive Using Self Constructing fuzzy Neural Network Controller", IEEE Trans. On Energy Conversion, Vol. 19, No. 1, March 2004.

[7] Purwanto Era, Studi Pengaturan Motor Induksi Dengan Metoda Vektor, Master Tesis, Universitas Shizuoka Jepang, 1995.

[8] C. T. Lin, "A Neural Fuzzy Control system With Structure And Parameter Learning", Fuzzy Sets Syst., vol. 70, no. 2-3, Mar. 1995, pp. 183-212.

[9] C. F. Juang and C. T.Lin, "An On-Line Self Constructing Neural Fuzzy Inference Network And Its Application", IEEE Trans. Fuzzy Syst, vol.6, Feb. 1998, pp. 12-32.

[10] Faa Jeng Lin, Rong Jong Wai, Chih Hong Lin dan Da Chung Liu, "Decouple Stator Flux Oriented Induction Motor Drive with
Fuzzy Neural Networks Uncertainty Observer", IEEE Trans. On Industrial Electronics, vol.47, No. 2, April, 2000, pp.356-367.

[11] R.Krishnan, VirginaTech. Blacksburg, VaElectric Motor Drives Modeling, Analysis and Control, Prentice Hall International. Inc., New Jersey, 2001.

[12] Soebagio, Era Purwanto, "Algoritma genetika Untuk Optimasi Penentuan parameter Motor Induksi dengan Model dq", SMED, 13 Juli 2000, hal. II-1.

[13] Soebagio, Mohammad Zuhri, "Pengaruh Perubahan Paremeter Terhadap Kinerja Motor Induksi Rotor Sangkar dan Rotor Belit", Proc. SITIA, Jurusan Teknik Elektro ITS, 2 Mei 2005, hal. 63-67.

[14] Mauridhi Hery P, Agus Kurniawan, Supervised Neural Networks dan Aplikasinya, Graha Ilmu, 2006.

[15] Soebagio, Peran Pengemudian Elektris dalam menghadapi Kompetisi Global, Pengukuhan Guru Besar, Surabaya, Januari, 2003.

[16] K. S.Narendra and K. Parthasarathy, "Identification And Control Of Dynamical Systems Using Neural Networks", IEEE Trans Neural Networks, vol. 1, Maret 1990, pp. 4-27.

[17] Boldea Ion, Nazar Syed A, Vector Control AC Drives, CRC Press, Inc.1992.

[18] Wiryajati K, et al, "Kontroller Konvensional Sebagai Model Referensi pada Pengaturan Motor Induksi Berbasis Field Oriented Control", Proc. CECI\&SITIA Control and Inteligent Teknology Application, Surabaya, 2003, pp.D40-D43. 